\title{
Zero-rating Food in South Africa: A Computable General Equilibrium Analysis
}

\author{
Marna Kearney ${ }^{1}$ \\ National Treasury, Pretoria \\ Jan $\mathbf{H}$ van Heerden \\ Department of Economics, University of Pretoria
}

\begin{abstract}
Zero-rating food is considered to alleviate poverty of poor households who spend the largest proportion of their income on food. However, this will result in a loss of revenue for government. A Computable General Equilibrium (CGE) model is used to analyze the combined effects on zerorating food and using alternative revenue sources to compensate for the loss in revenue. To prohibit excessively high increases in the statutory VAT rates of business and financial services, increasing direct taxes or increasing VAT to 16 per cent, is investigated. Increasing direct taxes is the most successful option when creating a more progressive tax structure, and still generating a positive impact on GDP. The results indicate that zero-rating food combined with a proportional percentage increase in direct taxes can improve the welfare of poor households.
\end{abstract}

JEL D58, H27

\section{1}

\section{Introduction}

In a report on poverty published by Statistics South Africa in 2000, it is stated that 49 per cent of South Africans spend less than R250 per month - the per capita poverty line (Statistics South Africa, 2000: 2). Low-income households consume the largest portion of their income, with food being the largest consumption expenditure item. Low-income households (income deciles zero to four) spend up to 40 per cent of their income on food, compared to high-income households (deciles eight and nine), which only spend 9 per cent (Thurlow \& Van Seventer, 2002).

Zero-rating Value Added Tax (VAT) on food can possibly reduce poverty and also inequality by reducing the regressive effect of the VAT system in South Africa. Because poor households spend a larger proportion of their income on consumption goods, they also spend a larger proportion of their income on VAT. This paper investigates the zero-rating of food and the implications of alternative sources that can be utilized to compensate the loss in revenue for government. Possible alternatives are increasing direct taxes, or applying higher VAT rates to other commodities and/or services. The impacts of zero-rating foodstuffs and the use of alternative sources of government revenue are analyzed using a CGE model. The incidence of zero-rating food, combined with an increase in taxes elsewhere, are analyzed in terms of changes in the regressiveness of VAT, the progressiveness of the complete tax structure, income distribution, the change in real consumption expenditure, and overall welfare. The impact on welfare is measured with an equivalent variation measurement. The impacts on economic growth, trade and other economic variables are also observed.

\section{2}

\section{Restructuring Value Added Tax}

The plan to change from a general sales tax (GST) to value added tax (VAT) was announced in the early 90s. VAT was implemented on 30 September 1991 at a rate of 10 per cent. The 
economic debate on VAT mainly focused on its redistributive nature. VAT is in nature regressive unless specific steps, like zero-rating essential foodstuff, are taken. This is the reason why certain food items were initially zero-rated. Brown bread, maize meal, samp, mealie rice, dried mealies, dried beans, lentils, pilchards, milk powder, milk, rice, unprocessed vegetables and fruit, vegetable oil, and eggs are some of the zero-rated food items (SA Tax, 2001: Schedule 2 Part B). The latest zero-rating was paraffin in 2001, to further assist poor households (RSA, 2001). However, in an interview on 21 February 2002, the Minister of Finance stated that there is no real evidence that the advantages of zerorating paraffin actually reached poor households as it was intended to.

Fourie and Owen (1993) conclude that VAT is mildly regressive, and that zero-rating, or applying differential VAT rates for different goods, would reduce some of its regressiveness. On the other hand, the advantages of such a tax system should not be eroded by administrative complications, or practical applicability that differential rates or zero-rating would impose. Zero-rating or differential rates might also create non-compliance and tax evasion. Lastly Fourie and Owen (1993) stress that direct social transfers could achieve the social goals of zerorating, instead. Other authors such as Sartorius von Bach and Van Zyl (1994) indicate that zerorating foodstuffs could achieve higher equality.

Zero-rating all food items (on top of those already zero-rated) can possibly improve the welfare of the poor by reducing the regressiveness of VAT, and at the same time increase the consumption of food. However, zero-rating all foodstuffs, in addition to those already zero-rated, would result in a loss of revenue for the government, since VAT is an important source of revenue. It is the second most significant revenue source for the government after direct income tax and in 2002 contributed 25 per cent to total tax revenue (SARB, 2003: S-54). Also, the government considers VAT to be a dependable and broadbased tax revenue source (RSA, 2002: 17). Therefore, it is important to offset any losses in revenue due to the zero-rating of foodstuffs, by alternative sources. Alternative sources investigated in this paper are increasing direct taxes and increasing VAT on other services. Direct taxes will be proportionally changed (increased) with an equal percentage, keeping the progressiveness of direct taxes in tact. Another alternative is applying higher VAT rates to commodities or services that are consumed mainly by higher income groups.

Although various authors suggest that zerorating food would improve the regressiveness of VAT and greater equality, the issue has not yet been investigated in an economy-wide framework. This paper investigates whether or not zero-rating food could provide immediate poverty relief; whether or not this would reduce regressiveness and inequality (especially when combined with other taxes), as well as the overall impact of such a policy measure on welfare. The impact of zero-rating on industry is also observed.

\section{3}

\section{Using a cge model to simulate changes in VAT}

For this application a CGE model is used to measure the impact of changes in VAT on the economy, and specifically income distribution. CGE models link prices with taxes, making them useful for the purpose of evaluating changes in the tax structure. They also allow for the evaluation of the impact of policy on distribution, because of the disaggregation of households in the model.

\subsection{The model}

In this paper a CGE model developed by Thurlow and van Seventer (2002) is used. ${ }^{2}$ The model is based on a standard CGE model developed by Löfgren et al. (2001). It follows the neoclassical-structuralist modelling tradition originally presented by Dervis, de Melo and Robinson (1982). The model employs the disaggregation of commodities, activities, factors and households as specified in the 1999 social accounting matrix (SAM) of South Africa, developed specifically for the model. The SAM allows for 43 commodities and activities at industry level; factors included 
are capital, high-skilled, semi-skilled, and unskilled labour. The households are divided into ten income deciles, with the tenth decile divided further into 95 per cent, 96,25 per cent, 97,5 per cent, 98,75 and 100 per cent respectively. Other entities included in the SAM are firms, the government and the rest of the world.

\subsection{Additions to the model for the purpose of this paper}

The South African model includes commodity taxes in an aggregate form. However, for the purpose of this paper it is necessary to isolate VAT, as the aim is to zero-rate VAT on food. VAT data for 1999 was obtained from the South African Standard Industry Database (TIPS, 2003). The first step is adjusting the SAM to separate VAT and other commodity taxes. Next, the CGE model is adjusted to include a separate specification of VAT. To do the simulation in this study it is necessary to include a statutory VAT rate variable, as well as a suitable equation linking the statutory VAT rate with the actual VAT rate.

The CGE model without the adjustment allows for one variable, namely $\operatorname{tq}(c)$ for all commodity taxes. In South Africa's case that would include VAT, excise duties, fuel levies and other taxes on products. We include more commodity tax variables to be able to separate VAT out, and to focus on zero-rating food. We also specify VAT in the model in such a manner that it captures the different effective VAT rates across the different commodities.

The following adjustments to the model are made:

1. The following equation is added:

\begin{tabular}{|c|c|}
\hline \multicolumn{2}{|c|}{ tvat $(c)=$ statvat $(c) *$ leakage $(c)$} \\
\hline where & \\
\hline tvat $(c)$ & is the actual VAT rate \\
\hline statvat $(c)$ & is the statutory VAT rate \\
\hline leakage $(c)$ & $\begin{array}{l}\text { is the ratio of the actual VAT } \\
\text { rate to the statutory VAT rate }\end{array}$ \\
\hline $\operatorname{tq}(c)$ & $\begin{array}{l}\text { other commodity taxes } \\
\text { (excluding VAT). }\end{array}$ \\
\hline
\end{tabular}

The parameter $t q(c)$ in the model is now equal to other commodity taxes (excluding VAT). Other commodity taxes specific to South Africa would include the fuel levy, excise duties, and other taxes on products.

2. statvat (c) is introduced in the model as a variable, since some simulations require the statutory VAT rate on certain commodities to adjust and absorb the loss in revenue due to the zero-rating of food. statvat(c) is, however, fixed (i.e., a fixed variable) so that it behaves as a parameter in the model. For the simulations where VAT on business and financial services adjusts statvat(c) is treated as endogenous and adjusts to the level required to finance the zero-rating of food. ${ }^{3}$

The last step is calibrating the new parameter leakage(c) and variable statvat(c). The VAT data included in the SAM are actual VAT receipts and therefore the VAT rate calibrated within the CGE model would be an actual (or effective) value-added tax rate. leakage(c) is calibrated as a ratio of the value of VAT revenues to total consumption expenditure divided by statvat(c) the statutory VAT rate, which is initially set equal to 14 per cent (the actual statutory VAT rate) for all commodities. VAT was also isolated in the expenditures on commodities by households as well as in government revenue.

\subsection{The simulations}

Zero-rating occurs when the rate of tax applied to sales is set to zero, though credit is still given for taxes paid on inputs (Ebrill et al., 2001: 3, Davis \& Kay, 1985: 5, SARS, 2003). When the commodity is zero-rated and the producers are allowed to receive a credit for inputs, VAT is equivalent to a consumption tax (Gottfried \& Wiegard, 1990: 2). We model VAT as a consumption tax, as it is levied on final demand.

First the impact of zero-rating food without any compensating tax adjustment is simulated. Second, zero-rating food with alternatives to offset the loss in revenue for government are simulated. The following alternatives are investigated: 


\section{i) Direct taxes}

Food is zero-rated and direct taxes are proportionally increased. Increasing direct taxes in this manner leads to a smaller absolute increase for lower-income groups, and a higher increase for higher-income groups, thereby maintaining progressiveness in the tax system.

\section{ii) Increased VAT rate on Commodities}

Intensively Used by High-Income

\section{Households}

High-income groups spend a larger portion of their income on business services and financial services compared to low-income groups (Thurlow \& Van Seventer, 2002). Increasing VAT on business services or financial services could lead to equity gains. This approach is followed as an alternative to taxing luxury items at a higher rate. Examples of business services are accounting, bookkeeping, legal services, engineering, marketing, and consulting services.

Financial services are not easily taxed since it is difficult to determine the value of the transactions. In South Africa not all financial services are taxable under VAT. Some of the services included are the sale of cheque book covers, charges for the provision of information to third parties, installation and rental of electronic payment devices, brokerage fees on derivative trading, cash value of rental agreements and vehicle maintenance agreements, rental of safety deposit boxes, bureau fees on payroll services (International VAT Monitor, 1995: 376). The list is not exhaustive. However, increased VAT receipts on financial services can also be achieved by including more services in the tax base.

\section{iii) Statutory VAT rate increase}

Another option is increasing the statutory VAT rate on all commodities not already zero-rated or excluded. Since this scenario does not allow for further exemption of specific commodities consumed by poor households we would expect a more regressive outcome in terms of welfare compared to the other scenarios mentioned above.

\subsection{Economy wide adjustment mechanisms}

A number of economy wide adjustment mechanisms (rules or constraints) are imposed on the model to achieve macroeconomic consistency. The choice of constraints will determine how the macroeconomic variables adjust in the modelled economy (Thurlow \& Van Seventer, 2002: 19). Our model allows us to specify different adjustment mechanisms for factor markets, the rest of the world, the government balance as well as domestic savings and investment.

Capital and high-skilled labour are assumed fully employed and activity specific, while unskilled and semi-skilled labour are assumed unemployed and mobile. For capital and highskilled labour the adjusting factor is wages; while for semi and unskilled labour the adjusting factor is employment, with wage rates assumed fixed.

With respect to the rest of the world, the exchange rate is assumed flexible, while foreign savings are fixed. This adjustment rule follows from observations made by Davies and Van Seventer (2003) who note that foreign savings as defined by the national accounts behaved relatively constant over the last 10 years.

In terms of the savings investment balance, investment is assumed as savings-driven. A paper by Nell (2002: 26) on the long-run exogeneity between saving and investment in South Africa finds that private savings are strongly exogenous to private investment in the period 1977 to 2001. It is for this reason that a savings-driven adjustment rule is chosen for the simulations. The savings rates of nongovernment institutions are fixed and the quantity invested adjusted with a flexible scalar ${ }^{4}$.

\subsection{Measurement issues}

The effectiveness of a tax can be measured by looking at the ability of the tax to raise revenue, the fairness of the tax and the cost incurred by the government and the taxpayer (Ebrill et al., 2001: 25).

The CGE model includes a large number of economic variables that allow one to observe 
the effects of changes in VAT on the effectiveness of the tax. Changes in these variables are observed during each simulation. Apart from these variables other issues such as the regressiveness of VAT, the progressiveness of the complete tax system, changes in real consumption expenditure, changes in income distribution, as well as the overall change in welfare are observed. The additional instruments are specified for the issues listed above, namely the regressiveness of VAT, the progressiveness of VAT and a Gini-coefficient. Regressiveness is measured by taking each household group's expenditure on VAT as a percentage of their total income. The progressiveness of the complete tax system is measured by taking the total payment of taxes by each household as a percentage of total income. A set of Gini coefficients is used to measure the impact of policy changes on distribution.

An exact welfare comparison between two equilibrium situations can be achieved with CGE models. The equivalent variation (EV) (as initially defined by Hicks, 1939) is often used to determine the welfare effect. It asks the question: "How much money is a particular change equivalent to?" The equivalent variation measures the amount after the price change that the household would be prepared to pay to return to old prices (Creedy, 1999: 12). Our model includes an indirect compensation (IC) and $\mathrm{EV}$ measurement. IC measures the income needed at base prices to generate the same welfare as before the simulation while EV measures the income change that, at base prices, would be equivalent to the change calculated for the simulation (Löfgren et al., 2001). The standard model also gives the EV value as a percentage of the initial consumption value (EVTAB). This measure is used to evaluate the impact of the simulations of the welfare of the household deciles.

\section{4 \\ Results}

Our simulations suggest that increasing the statutory VAT rate on business and financial services to compensate for the loss in government revenue due to the zero-rating of food would be unrealistic. The statutory VAT rate on business services should be increased to 42,4 per cent (which is an increase of more than 200 per cent) to compensate for the loss in revenue. The Fiscal Advisory Department of the IMF advised a rate of 11 to 19 per cent (Ebrill et al., 2001: 65). Similar results were obtained when increasing VAT on financial services: the regressive VAT was turned into a progressive VAT, but the statutory VAT rate on financial services had to be increased to 91 per cent (which represents an increase of almost 550 per cent), which is even more unrealistic.

The rest of this section therefore focuses on the results obtained for the other simulations, namely zero-rating food without any revenue compensating scheme, zero-rating food with an increase in direct taxes, and lastly zero-rating food while increasing the statutory VAT rate of other commodities to 16 per cent. Table 1 shows the effects of zero-rating food on GDP from both the expenditure and income sides.

With no compensation GDP only declines with 0,06 per cent if food is zero-rated, and with an increase in all other rates to 16 per cent, the decline is equal to 0,09 per cent. When government revenue is kept neutral (through an increase in direct taxes), the net effect of eliminating VAT on food is an increase in GDP by 0,01 per cent. The change in GDP is relatively small and is due to changes in the composition of aggregated demand. Real private consumption increased for all simulations due to the zero-rating of food with the largest increase at 0,69 per cent when no other taxes are increased. If the composite price of food decreases (due to the zero-rating of food) consumption increases. Investment decreases to counter balance the increase in household consumption. The reason for this is: if the budget deficit goes up, domestic savings decline. Given fixed foreign savings, and fixed private savings rates assumed, the only variable that is then allowed to adjust is investment. Hence investment will decline and counterbalance the increase in household consumption to such a degree that GDP as a whole decreases. When direct taxes are adjusted the decrease can be 
attributed to a lower marginal propensity to save. In this simulation a balanced budget is assumed with direct taxes the adjusting variable. In other words, direct taxes increase to offset the decline in government revenue. Consequently, total household expenditure does not increase as much as in the previous simulation and therefore private sector investment does not have to adjust downwards as much since most of the adjustment is already achieved by household expenditure itself. Nevertheless, the net effect is not negative for GDP - in fact it is slightly positive.

Table 1

Effects of zero-rating food - changes in real GDP

\begin{tabular}{|c|c|c|c|c|c|c|c|c|}
\hline & \multirow[b]{2}{*}{ Base } & \multirow[b]{2}{*}{$\begin{array}{c}\text { Share of } \\
\text { GDP }\end{array}$} & \multicolumn{2}{|c|}{ No compensation } & \multicolumn{2}{|c|}{$\begin{array}{l}\text { With increase in } \\
\text { direct taxes }\end{array}$} & \multicolumn{2}{|c|}{$\begin{array}{l}\text { With increase in } \\
\text { other VAT rates }\end{array}$} \\
\hline & & & $\begin{array}{l}\text { Percen- } \\
\text { tage } \\
\text { change }\end{array}$ & $\begin{array}{l}\text { Contri- } \\
\text { bution }\end{array}$ & $\begin{array}{l}\text { Percen- } \\
\text { tage } \\
\text { change }\end{array}$ & $\begin{array}{l}\text { Contri- } \\
\text { bution }\end{array}$ & $\begin{array}{c}\text { Percen- } \\
\text { tage } \\
\text { change }\end{array}$ & $\begin{array}{l}\text { Contri- } \\
\text { bution }\end{array}$ \\
\hline $\begin{array}{l}\text { Consump- } \\
\text { tion }\end{array}$ & 505,69 & 0,60 & 0,69 & 0,41 & 0,19 & 0,11 & 0,07 & 0,04 \\
\hline $\begin{array}{l}\text { Fixed } \\
\text { capital } \\
\text { formation }\end{array}$ & 124,20 & 0,15 & $-3,22$ & $-0,47$ & $-0,70$ & $-0,10$ & $-0,85$ & $-0,12$ \\
\hline $\begin{array}{l}\text { Govern- } \\
\text { ment } \\
\text { consump- } \\
\text { tion }\end{array}$ & 192,11 & 0,23 & No change & 0 & No change & 0 & No change & 0 \\
\hline Exports & 205,88 & 0,24 & $-0,36$ & $-0,09$ & $-0,08$ & $-0,02$ & $-0,20$ & $-0,05$ \\
\hline Imports & $-184,03$ & $-0,22$ & $-0,40$ & 0,09 & $-0,09$ & 0,02 & $-0,23$ & 0,05 \\
\hline $\begin{array}{l}\text { GDP at } \\
\text { market } \\
\text { prices }\end{array}$ & 847,11 & 1 & $-0,06$ & 100 & 0,01 & 100 & $-0,09$ & 100 \\
\hline $\begin{array}{l}\text { Net } \\
\text { indirect } \\
\text { taxes }\end{array}$ & 90,00 & 0,11 & $-0,08$ & $-0,01$ & 0,03 & 0,00 & $-0,13$ & $-0,01$ \\
\hline $\begin{array}{l}\text { GDP at } \\
\text { factor } \\
\text { cost }\end{array}$ & 758,11 & 0,89 & $-0,07$ & $-0,05$ & 0,01 & 0,01 & $-0,08$ & $-0,07$ \\
\hline
\end{tabular}

Source: CGE simulations (Thurlow \& Van Seventer, 2002)

In the third simulation, in which VAT on all other goods are increased so as to attempt to balance the budget, private consumption expenditure does not change significantly. The reason is the same as in the second simulation. However, investment decreases with more than in the previous simulation, presumably because investment demand is also negatively impacted by the increase in VAT on all other goods directly. Table 2 shows the average effective tax rates of households before and after zero-rating food, while increasing direct taxes.
Table 2

Rate of direct taxes on firms and households

\begin{tabular}{|l|c|c|}
\hline & Base (\%) & Zerodirectsav (\%) \\
\hline Hhd0 & 0,07 & 0,07 \\
\hline Hhd1 & 1,10 & 1,14 \\
\hline Hhd2 & 2,40 & 2,50 \\
\hline Hhd3 & 5,30 & 5,51 \\
\hline Hhd4 & 8,10 & 8,43 \\
\hline Hhd5 & 9,60 & 9.99 \\
\hline
\end{tabular}




\begin{tabular}{|l|l|l|}
\hline Hhd6 & 11,30 & 11,75 \\
\hline Hhd7 & 13,80 & 14,35 \\
\hline Hhd8 & 17,50 & 18,20 \\
\hline Hhd91 & 19,20 & 19,97 \\
\hline Hhd921 & 17,60 & 18.31 \\
\hline Hhd922 & 16,70 & 17,37 \\
\hline Hhd923 & 19,00 & 19,76 \\
\hline Hhd924 & 15,10 & 15,71 \\
\hline
\end{tabular}

Source: CGE simulations (Thurlow \& Van Seventer, 2002)

When food is zero-rated without a revenue replacement strategy imports decline due to the higher import content of investment demand compared to household expenditure. Given fixed foreign savings, exports have to decline, which is achieved with an appreciation of the exchange rate. The real exchange rate appreciates by 0.3 per cent as total imports decline more than total exports. In the second simulation (in which food is zero-rated while direct taxes increase) imports and therefore also exports go down for the same reason as before but not with as much and the exchange rate stays virtually constant. In the third simulation (in which food is zero-rated in VAT increase to absorb the loss in revenue) investment is affected more and therefore the impact on imports and exports is slightly higher than in the previous simulation.

Food prices decrease by 5.5 per cent due to the zero-rating of food. However, the price of food only decreases by 3.5 per cent. The offsetting factor is a relatively large increase in the imports of food ( 3.3 per cent). The relatively large increase in imports is due to both an income and substitution effect. The income effect, in turn, is due to lower import prices, which declined by 0.2 per cent. The substitution effect is due to a change in the relative price of imported foods to domestically produced foods - import prices declined by 0.2 per cent compared to an increase in the price of domestic demand of 2.2 per cent.

The relatively larger than expected increase in food imports resulted in a smaller than expected decrease in the composite price of food. The zero-rating of food and the resultant decline in the composite price of food generate an income effect that causes both imports and domestic production to increase. Domestic production increases by 1.6 per cent. There is a substitution away from exports as food exports decline by 4.6 per cent. Food is also used intensively in the production of food itself, a factor that in turn results in a larger decrease in the price of food. The net effect (modelled effect) is a decline in food prices of 4.2 per cent.

The agricultural industry benefits from zerorating food as agricultural products are used intensively in the production of food agricultural products contribute 56 per cent of total intermediate use in the food industry. The agricultural industry, in turn, also uses food as an intermediate good - 20 per cent of total intermediate use. The resultant effect is a relatively large increase in activity in the agricultural industry. Imports of agricultural goods increase by 1.4 per cent due to lower import prices and domestic supply by 0.5 per cent. Other industries that also benefit (because they are using food as an intermediate) are beverages and tobacco, hotel and accommodation and the leather industry. The leather industry benefits because food (mainly meat) contributes to 66 per cent of total intermediate use. Domestic sales of leather increase by 1.4 per cent, while imports decline by 3.1 per cent. Exports of leather increase by 3.6 per cent. Most of the domestic sales of leather are for intermediate use by the footwear industry. This is then the reason why the footwear industry also benefits from zero-rating food. The service industries in general benefit from zero-rating food as most of the services use food as an intermediate. Service industries also benefit from lower import prices.

Industries that do not benefit are the industries that sell mostly to investment. The construction industry is an example of an industry that performs very poorly. It sells 58 per cent of total sales to investment. As investment demand decreases by 3.3 per cent, demand for construction will also decrease. The domestic supply of construction decreases by 2.3 per cent. The construction industry imports a very small share of total domestic demand ( 0.8 per cent) and therefore does not benefit to a great extent from lower import prices. 
The same patterns are observed when zerorating food with revenue replacement strategies, although the import effect is smaller as the exchange rate appreciates under both cases. The investment effect is also less severe in both cases.

GDP at factor cost is equal to value-added, and the change in value-added is determined by a change in employment of unskilled and semiskilled labour (as high-skilled labour and capital are assumed exogenous). Without tax compensation the employment of unskilled labour decreases by 0.12 per cent, while employment of semi-skilled labour increases slightly by 0.06 per cent - the decline in indirect taxes only contributes 0.01 per cent in the overall decline in GDP. If the VAT rate increases for other commodities, employment of unskilled labour decreases by 0.03 per cent while semi-skilled employment declines by 0.24 per cent. The large decline in semi-skilled labour is due to an intensive use of semi-skilled labour within most industries. If direct taxes are increased, employment of unskilled labour increases by 0.28 per cent while employment of semi-skilled labour declines slightly by 0.01 per cent. The combination of zero-rating food and increasing direct taxes results in a substitution of semi-skilled labour for unskilled labour. The change in GDP at factor cost and the resultant change in industry activity will in turn influence the use of production factors capital and labour.

The change in household factor income from capital and high-skilled labour is associated with changes in the activity specific rental price of capital and the activity specific wage for highskilled labour respectively, as capital and employment of high-skilled labour are assumed fixed. The change in household factor income for semi- and unskilled labour is due to changes in their employment. When zero-rating food without compensation the factor income of unskilled labour decreases due to the average decline in employment of unskilled labour of 0.12 per cent. When government revenue is kept neutral (through an increase in direct tax rates), the net effect of eliminating VAT on food is an increase in factor income for all factors with the largest increases for capital and high-skilled labour. An increase in other VAT rates causes all factor income of households to decline, with capital and high-skilled labour showing the largest decline.

In 1999 poor households paid up to four per cent of their income to VAT compared to highincome households paying only 2.5 per cent. Zero-rating food will reduce the regressiveness of VAT. The VAT payments for the households are reduced by 43.4 per cent, compared to 14.6 per cent for high-income households in the cases of no compensation and compensation through direct taxes. The direct tax rate needs to increase proportionately by four per cent for all households, to absorb the loss in revenue due to the zero-rating of food.

Fourie and Owen (1993) as well as Davis and Kay (1985) stress that the regressiveness of VAT should be considered taking the complete tax structure into account, specifically against the progressive nature of income tax. Zero-rating food without a revenue replacement strategy does not have a significant impact on the progressiveness of the complete tax system. Replacing the revenue with either direct taxes or higher VAT on commodities will effectively lower the total tax burden for poor households while at least retaining the total tax burden for high-income groups at existing levels. Compensation through direct taxes is the most efficient way in improving the progressiveness of the complete tax system. The total tax burden of poor households is reduced by 32 per cent while the tax burden of the high-income households is increased by 1.3 per cent.

The pre- and post-tax Gini coefficients give an indication of equality taking both income and the progressiveness of the tax structure into account and the L-measure gives the extent of the reduction in inequality arising from the tax system. The 1999 pre-tax Gini Coefficient of 0.56 is comparable with a Gini Coefficient of 0.59 published by Statistics South Africa based on the 1995 household survey, and taking into account income and expenditure (Stats SA, 2000: 83). The difference is attributed to the aggregated nature of the household data contained in the SAM. Zero-rating food while increasing VAT on all other commodities was the only simulation that generated a pre-tax equity gain. Low-income households provide 
mainly unskilled and semi-skilled labour, which are more adversely affected by zerorating food. Increasing direct tax rates in turn results in the largest post-tax equity gains, illustrating the ability of direct taxes to generate progressiveness. The L-measure ${ }^{5}$ gives the combined change in income distribution. Zerorating food while increasing direct taxes resulted in the largest equity gains. Therefore, zero-rating food while increasing direct taxes proportionately, can improve the inequality of income distribution in South Africa.

Zero-rating food leads to an improvement in the consumption value of low-income households - the EV increased with up to 1.5 per cent with the direct tax compensation. Without a revenue replacement strategy the consumption value of high-income households increases as much as 2.4 per cent; with a revenue replacement strategy the EV value for highincome groups decline. When increasing VAT on other commodities, the EV value declines by 1.5 per cent. The main reason for this is the change in factor income. Factor income of highskilled labour and capital declines to a large extent and as high-income households receive the largest percentage of their income from high-skilled labour and capital, it affects them the most.

The changes in welfare are driven by the combined changes in prices, production, employment and factor prices (and therefore income). Zero-rating food will result in a decline in income for low-income households compared to high-income households. With no compensation or with a change in direct taxes the decline in employment for unskilled and semi-skilled labour results in a decline in income for low-income households. On the other hand there is an average increase in the industry specific wages of high-skilled labour and on the industry specific rental price of capital. Although the income of poor households declines, overall welfare improves as the price effect of zero-rating food outweighs the decline in income.

\section{5}

\section{What the model does not say}

The zero-rating of food, while increasing VAT on other commodity or services, will introduce more statutory VAT rates. Applying differential VAT rates carries cost in terms of increased administration as well as compliance cost. It also makes politicians, or the government, vulnerable to lobbying and the political powers of producers and other interest groups (Ebrill et al., 2001: 80). The administration and compliance cost of VAT increases when applying differential rates because it complicates the taxpayers' books and invoices; it also complicates audits, creates scope for argument and creates incentive for deliberate misclassification of items. With a multiple VAT rate system, the compliance cost rises as the tax forms become more complex and accounting records need to be more complete (Agha \& Haughton, 1996: 304). The administrative and compliance cost of VAT is not measured within the CGE model, and to incorporate these costs a function form of some sort must be specified accordingly and data on these issues be applied.

Also, taxing services more, as was hinted at earlier, is likely to lead to self-supply, which is not the case with commodities (Kay \& Davis, 1986). The model furthermore does not include a function that specifies the substitutability between services obtained and services being self-supplied.

\section{6}

\section{Conclusion}

Zero-rating food can reduce poverty by lowering food prices and at the same time lowering the regressiveness of VAT if it is combined with a proportional increase in direct taxes.

The food industry benefits to a larger extent from the zero-rating of foodstuffs than the initial drop in VAT, as food is also used as an intermediate in the production of food. Other industries that benefit from the zero-rating of food are industries that use food as an intermediate good, or industries producing 
goods used as an intermediate in the production of food.

The model, however, does not say anything about the administrative and compliance costs imposed when applying differential rates. Imposing differential rates leads to increased administrative costs and increased compliance costs which in turn lead to more evasions. Also increasing the VAT on services, such as business and financial services suggested here, could possibly lead to self-supply. The implication of applying differential rates should be investigated before such a policy strategy could be followed.

\section{Endnote}

1 Financial assistance from TIPS is acknowledged.

2 For a detailed discussion of the South African CGE model, see Thurlow and Van Seventer (2002).

3 This is achieved through an additional closure programmed in the model.

4 All simulations assuming investment is savings-driven, is SAV appended.

5 The L-measure is simply calculated as the net change in the Gini Coefficient pre- and post tax.

\section{References}

1 AGHA, A. \& HAUGHTON, J. (1996)

"Designing VAT systems: Some efficiency considerations", The Review of Economics and Statistics, 58(2): 303-08.

2 CREEDY, J. (1999) "Modelling indirect tax reform in Australia: Should tax rates be uniform?", Melbourne Institute Working Paper Series. Melbourne Institute of Applied Economic and Social Research, 6/99.

3 CREEDY, J. (2001) Taxation and Economic Behaviour. An Introduction in Surveys in Economics, Vol I, Edward Elgar: UK.

4 DAVIES,R. \& VAN SEVENTER, D.E. (2003) "A gap and macro decomposition analysis for South Africa, 1993-2002", http://www.tips.org.za.

5 DAVIS, E.H. \& KAY, J.A. (1985) "Extending the VAT base: Problems and possibilities", Fiscal Studies, 6(1): 1-16.
6 EBRILL, L., KEEN, M., BODIN, J. \& SUMMERS, V. (2001) The Modern VAT, International Monetary Fund: Washington D.C.

7 FINANSIES \& TEGNIEK. (2002) "Trevor Manuel justifies VAT”, 22 February, http://www. fnt.co.za.

8 FOURIE, F.C.v.N. \& OWEN, A. (1993) Valueadded tax and regressivity in South Africa", South African Journal of Economics, 61(4).

9 GOTTFRIED, P. \& WIEGARD, W. (1990) "Exemption versus zero-rating: A hidden problem of VAT", Paper presented at the Applied General Equilibrium Modelling Workshop, Washington D.C: World Bank.

10 INTERNATIONAL VAT MONITOR. (1995)

"Services rendered by financial services intermediaries, additional information", 6(6) November/December 1995: South Africa.

11 KAY, J.A. \& DAVIS, E.H. (1986)" The VAT and services", Paper Presented at The Conference on Value Added Taxation in Developing Countries. The World Bank: Washington D.C.

12 LÖFGREN, H., HARRIS, R.L., \& ROBINSON, S. (2001) "A standard computable general equilibrium (CGE) model in GAMS", Discussion Paper No. 75(May), Trade and Macroeconomics Division International Food Policy Research Institute: 8-19.

13 McDONALD, S., PIESSE, J. \& VAN ZYL, J. (2000) "Exploring the distribution of household income in South Africa", The South African Journal of Economics, 68(3): 423-54.

14 NELL, K.S. (2002) "Long-run exogeneity between saving and investment: Evidence from South Africa", TIPS Working Paper, 2, Internet: http://www.tips.org.za.

15 REPUBLIC OF SOUTH AFRICA (2001) Budget Speech, Minister Trevor Manuel. http:// www.gov.za.

16 REPUBLIC OF SOUTH AFRICA (2002) Budget Speech, Minister Trevor Manuel. http:// www.gov.za.

17 SARB (2003) Quarterly Bulletin, March.

18 SARS (2003) "General guidelines for VAT", Internet: http://www.sars.gov.za/v_a_t/.

19 S.A. TAX (2000-2001) Income Tax, ValueAdded Tax, Estate Duty and Transfer Duty, Compiled by Roeleveld, J. (4 $4^{\text {th }}$ ed.) Kadimah Trading: Cape Town.

20 SARTORIUS VON BACH, H.J. \& VAN ZYL, J. (1994) "Effects of value-added tax (VAT) on inequality of agrarian household expenditures: Evidence from Lebowa, Venda and Kangwane", 
South African Journal of Economic and Management Sciences, 14(Summer).

21 SHOVEN,J.B. \& WHALLEY, J. (1992) "Designing an applied general equilibrium model", Chapter 4 in Applying General Equilibrium, Cambridge Surveys of Economic Literature: Cambridge: 71-102.

22 STARR, R.M. (1997) General Equilibrium Theory. An Introduction, Cambridge University Press: UK.

23 STATISTICS SOUTH AFRICA. (2000) Measuring poverty in South Africa, Internet: http://www.statssa.gov.za.

24 STATISTICS SOUTH AFRICA, Time Series Data. http://www.statssa.gov.za.
25 THURLOW, J. \& VAN SEVENTER, D. (2002) A Standard Computable General Equilibrium Model for South Africa. Internet: http:// www.tips.org.za.

26 TIPS. South Africa Standard Industry Database. http://www.tips.org.za.

27 VAN RENSBURG, T. (2003) Discussion on Gini Coefficient. Excel Calculation. World Bank: Washington D.C.

28 WORLD BANK SIMPOSIUM (1990) ValueAdded Taxation in Developing Countries, Gillis, M., Shoup, C.S. \& Sicat, G.P. (eds.) Washington D.C: The World Bank. 